This work is licensed under a Creative Commons Attribution 4.0 International License.

Ovaj rad dostupan je za upotrebu pod međunarodnom licencom Creative Commons Attribution 4.0.

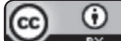

https://doi.org/10.31820/f.30.2.7

Anera Ryznar

\title{
PRAGMASTILISTIKA LIRSKE PJESME (Ivan Slamnig: Kad mi svega bude dosta)
}

dr. sc. Anera Ryznar, Filozofski fakultet, anera.ryznar@gmail.com, Zagreb

izvorni znanstveni članak

UDK 82.09-1

821.163.42.09Slamnig, I.-1

rukopis primljen: 1. 9. 2018.; prihvaćen za tisak: 15. 11. 2018.

U radu se skicira moguće područje preklapanja stilistike i pragmatike kako bi se oblikovao novi hermeneutički model za interpretaciju lirskoga teksta. Na početku se nude osnovne infomacije o pragmatici kao disciplini, njezinim začetnicima (H. P. Griceu i J. L. Austinu) i temeljnim konceptima (deiksi i govornim činovima) iz kojih se derivira opća teza o performativnosti književnoga diskurza (Sh. Felman) s kojom je povezana i performativna hipoteza na kojoj se ustrojava lirska komunikacija (S. Levin). U središnjem dijelu rada nudi se pragmastilističko čitanje pjesme Kad mi svega bude dosta Ivana Slamniga. Pjesmu se najprije smješta u kontekst Slamnigova lirskog opusa te krugovaške poetike, a potom se izdvajaju i opisuju njezina osnovna stilska obilježja: prividna "lakoća” i komunikativnost, utjecaj 'kolokvijalnog' stila, uredna i simetrična kompozicija, metrički i versifikacijski postupci (trohejski osmerac, leoninska rima, izosilabičnost). Teza od koje analiza polazi jest da pjesma, koja se na prvi pogled čini pristupačnom i razumljivom, iz pragmastilističke perspektive izgleda bitno drukčije: njezina se „lakoća” pokazuje kao iluzija jer lirski subjekt specifičnim jezičnim i stilskim izborima (govornim činovima komisivima, specifičnom upotrebom deikse, foričkim odnosima i glagolskim vremenima) otežava (čak opstruira) lirsku komunikaciju. Interpretacija je stoga ponajviše usredotočena na autoreferencijalnost i performativnost Slamnigova pjesničkog diskurza nasuprot tradicionalnim konstativnim interpretacijama zaokupljenima dešifriranjem tekstualnih značenja.

Ključne riječi: pragmatika; stilistika; deiksa; govorni činovi; lirska pjesma; Ivan Slamnig 


\section{Uvod u pragmastilistiku}

Polazeći od spoznaje da je diskurzivni zaokret, koji je u zadnjih tridesetak godina suštinski promijenio način na koji stilistika vidi i proučava književni tekst, ujedno otvorio i mogućnost oblikovanja novih, interdisciplinarnih hermeneutičkih modela, u ovome se radu želi predstaviti jedan takav model koji nastaje stapanjem stilističke interpretacije lirskoga teksta i pragmatičkih uvida u prirodu jezične komunikacije. Dok je stilistička metoda dobro poznata i odavna ugrađena u studij nacionalne književnosti pa ju ne treba dodatno pojašnjavati, o pragmatičkom pristupu ipak je potrebno reći nekoliko riječi, i to ne samo zato što se radi o primarno lingvističkoj disciplini, nego i zato što je u kontekstu domaće znanosti o književnosti njezina primjena zasad prilično skromna i neprepoznata ${ }^{1}$.

Naziv pragmatika izvorno je nastao u sklopu semiotičke teorije američkog lingvista Charlesa Morrisa (1938), koji je predložio razlikovanje između sintakse, semantike i pragmatike. Dok se sintaksa bavi kombiniranjem znakova, a semantika odnosom znaka i njegovog referenta, pragmatika je lingvistička disciplina koju prvenstveno zanima način na koji ljudi tumače jezične znakove te koriste jezik da bi postigli određene ciljeve. U skladu s tim, pragmatika proučava metode i posljedice jezičnoga djelovanja i uvjete u kojem se to djelovanje odvija.

Metodološki aparat kojim se pragmatika tradicionalno služi uglavnom je deriviran iz radova britanskih filozofa Johna Langshawa Austina i Paula Gricea, koji se smatraju začetnicima pragmatičke discipline. Tako Austin u svojoj kapitalnoj studiji How to Do Things with Words $(1962)^{2}$ uvodi teoriju govornih činova te uspostavlja razliku između onoga što riječi znače i onoga što se njima može činiti, dok Grice u knjigama Logic and Conversation $(1975)^{3}$ i Studies in the Way of Words (1989) analizira strukturu konverzacije

1 U tom malom korpusu ipak se izdvaja studija Marine Katnić Bakaršić Stilistika dramskog diskursa (2003) te rasprava Tatjane Pišković Dramski diskurs između pragmalingvistike i feminističke lingvistike (2007). Pragmastilističkih čitanja poezije i proze kod nas zasad nema. $S$ druge strane, u inozemnoj, a posebice anglofonoj humanistici od devedesetih naovamo objavljeno je nekoliko važnih studija i zbornika koji su zacrtali koordinate pragmastilistike (Hickey 1989; Sell 1991; Black 2006, Chapman i Clarke 2014).

2 Austina u tekstu citiram prema hrvatskom prijevodu: Austin, John Langshaw (2014) Kako djelovati riječima, prev. A. Milanko, Disput, Zagreb.

3 Grice, H. Paul (1987) „Logika i razgovor”, Kontekst i značenje, ur. Nenad Miščević i Matjaž Potrč, Izdavački centar Rijeka, Rijeka, 55-67. 
te uvodi pojam implikatura i načela kooperativnosti na kojima se temelji konverzacijska razmjena. Samo godinu dana nakon što je Grice objavio svoju studiju Logic and Conversation Teun Van Dijk je primijetio da se Griceova načela dobrim dijelom odnose na strukturu samoga iskaza pa se stoga mogu smatrati stilističkima i primijeniti u analizi književnih tekstova (Usp. Dijk 1976: 44). Tako su Griceove teze ušle u studij književnosti, ali prvenstveno u proučavanje dramskoga teksta i njegove dijaloške strukture. Austinova je teorija s druge strane doživjela golemu popularnost i gotovo da nema jezične prakse na koju nije primijenjena, pa tako naravno i na književnost.

Što se tiče povezivanja pragmatike i stilistike, ono je na neki način logično s obzirom na to da su obje discipline zainteresirane za izbore koje govornik čini iz raspoloživog jezičnog repertoara, premda pragmatiku zanima kako ti izbori utječu na obavljanje određene radnje, a stilistiku kakve posljedice ti izbori imaju na jezičnoj odnosno stilskoj razini teksta te kakav učinak imaju na recipijenta. Nastojeći razgraničiti dvije discipline i skicirati područje njihova preklapanja, pragmastilističar Leo Hickey ponudio je sljedeće pojašnjenje: „Ako lingviste zanima ‘što si rekao', stilističare 'kako si to rekao', pragmatičare 'što si učinio', tada pragmastilističare zanima 'kako si učinio to što si učinio'" (Hickey 1993: 584).

Budući da je pragmatika prvenstveno zaokupljena jezičnim strategijama s pomoću kojih tekst uspostavlja vezu sa svojim izvanjezičnim kontekstom, odnosno uz pomoć kojih se u tom kontekstu „sidri”, ona posebnu pažnju posvećuje analizi deikse, odnosno deiktičkih ili upućivačkih riječi u koje, između ostalog, ubraja osobne, pokazne i neodređene zamjenice, glagolska lica i vremena, mjesne i vremenske priloge te određeni i neodređeni pridjevski vid. S obzirom na to da deiksa svoje temeljno značenje dobiva u tzv. kanonskoj diskurznoj situaciji (živom razgovoru oči u oči), njezina upotreba u pisanim, a pogotovo u fikcijskim tekstovima bit će drugačija nego u svakodnevnoj usmenoj komunikaciji. Naime, budući da se književni tekst ne referira izravno na izvanknjiževnu zbilju, njegova deiksa neće imati funkciju kontekstualnog sidra, nego će imati gotovo pa svjetotvornu ulogu. Deiktičke riječi služit će tome da se u književnome tekstu kreira dimenzija prostora i vremena, dakle da se uspostavi prostorno-vremenski okvir fikcijskoga svijeta, da se odredi pozicija lica koje govori (gledište, perspektiva) te da se uspostave odnosi između govornika (pripovjedača, lirskih subjekata) i drugih lica koji taj svijet nastanjuju. Kada govorimo o deiksi u poeziji, treba podsjetiti i na to da je u kontekstu književnosti lirski diskurz specifičan. U njemu vrijede posebna pravila koja se tiču vremena, prostora, glasova, 
uzročno-posljedičnih veza, linearnosti i sl. Naime, često se kaže da lirska pjesma živi u svojevrsnom bezvremenom prezentu, a to zapravo znači da njezino vrijeme nije, kao, primjerice u romanu, vrijeme priče odnosno vrijeme iskaza, nego je to vrijeme diskurza, vrijeme iskazivanja. Stoga se lirska pjesma nerijetko naziva neposrednim govornim činom, što nam omogućuje da u pragmastilistički pristup lirici uključimo i teoriju govornih činova.

Nije naodmet podsjetiti da je Austin tu teoriju počeo graditi na distinkciji između konstantiva, opisnih iskaza kojima se ustvrđuje stanje stvari i na koje se može primijeniti kriteriji istinitosti/neistinitosti, i performativa, koji ne opisuju svijet, nego ga ustrojavaju i mijenjaju i to tako što doista izvode radnju na koju se referiraju. Za razliku od konstativa performativi ne mogu biti ne/istiniti, nego samo posrećeni ili nesposrećeni što ovisi o tzv. uvjetima posrećenosti - okolnostima u kojima će se performativ ostvariti svoje djelovanje. Razrađujući pitanje performativa, Austin je svoj pristup proširio na cijelo jezično područje koje je promatrao kroz tri potencijalna aspekta - lokuciju, ilokuciju i perlokuciju ${ }^{4}$ - te se potom usmjerio na ilokucijske činove koje je podijelio na pet osnovnih tipova: verdiktive ili zabrane, egzercitive ili naredbe, behabitive ili postupke društvene ophodnje, ekspozitive ili izlaganja i komisive ili obaveze (Austin 2014: 108-116). ${ }^{5}$

Budući da je Austinova teorija proizašla iz proučavanja jezika u njegovoj komunikacijskoj, a ne literarnoj ulozi, prije no što je stavimo u funkciju interpretacije lirske pjesme, moramo se zapitati o legitimnosti primjene te teorije u studiju književnosti. Naime, Austin je i sam napomenuo da se njegova teorija ne odnosi na "neozbiljne”, „parazitske” ili „ne posve normalne” upotrebe jezika (Usp. Austin 2014: 15) u koje je ubrojio i poeziju, a pritom je mislio na one upotrebe jezika u kojima referencija funkcionira na drugačiji način, a i uvjeti posrećenosti ne mogu se ispuniti. Zato su Austinovi nasljednici govorne činove u književnosti nazivali mimetičkim govornim činovima, pseudo- ili kvazigovornim činovima, šupljim činovima i slično. No, bilo je i teoretičara koji su tvrdili da se tu teoriju bez problema može primijeniti na

4 Lokucija je bilo koji čin iskazivanja koji poštuje sintaktička pravila i ima neko značenje; ilokucija je čin izveden kazivanjem, dimenzija u kojoj jezik ostvaruje snagu i moć utjecaja na druge, a perlokucija je učinak koji na čitatelja/slušatelja ima ilokucijski čin.

5 Austinovu klasifikaciju komentirali su i proširivali njegovi brojni nasljednici, npr. John Searle (Usp. 1991) te Elizabeth Traugott i Mary Louise Pratt (Usp. 1980). Tako se bi se navedenoj tipologiji moglo pridodati i reprezentative (tvrdnja, kazivanje), ekspresive (divljenje, poštovanje, prijezir), direktive (naredba, molba, zahtjev) i deklarative (vjenčanje, presuda, otpuštanje, blagoslov). 
književni tekst. Najglasnije je to u svojoj studiji Toward a Speech Act Theory of Literary Discourse (1977) zagovarala Mary Louise Pratt, a pojedini su teoretičari čak ustvrdili da bi se cijela pjesma, poezija kao takva, pa onda i cjelokupna književnost trebala promatrati kao jedan veliki govorni čin i to naravno performativ. ${ }^{6}$ Tako primjerice, u članku Concerning What Kind of Speech Act a Poem Is američki teoretičar Samuel Levin (1976: 149-150) pretpostavlja da se u dubinskoj strukturi svake pjesme nalazi sljedeća rečenica:

Zamišljam sebe, a i vas pozivam da se zamislite u svijetu u kojemu...

Naravno, ta rečenica nikada neće biti vidljiva na površinskog razini teksta, nikada neće se artikulirati, ali ona predstavlja implicitni performativ na kojemu se ustrojava književni diskurz. To je ono što je još Austin nazvao performativnom hipotezom. Drugim riječima, prema Levinu, pjesma je ilokucijski čin u kojemu pjesnik uz pomoć performativnih glagola pozvati i zamisliti nagovara čitatelja da projicira sebe u jedan drugi svijet, da zauzme poziciju lirskog adresata i da prihvati sve što se u njemu zbiva kao moguće - da dobrovoljno obustavi svoju nevjericu. Kad se performativna hipoteza uvrsti u shemu književne komunikacije, dobivamo sljedeći model"7:

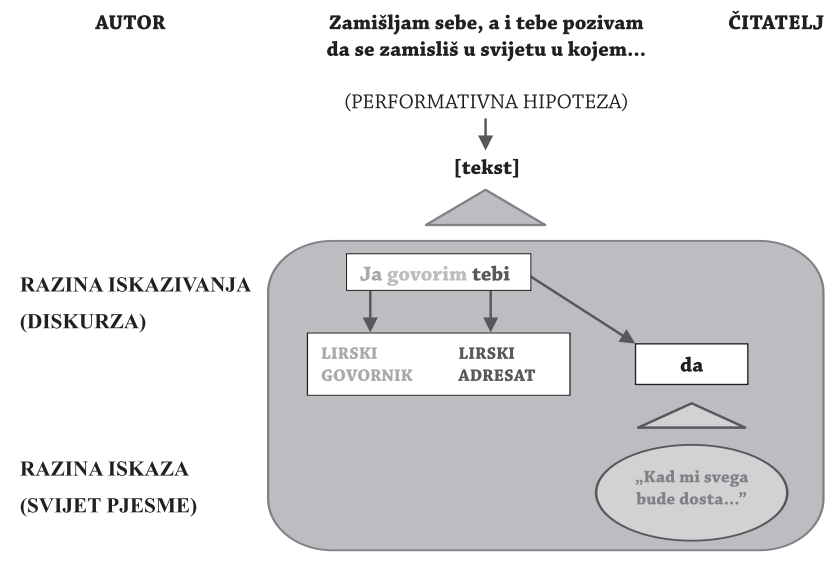

6 Ovdje valja spomenuti da su iscrpnu i vrlo poticajnu teorijsku diskusiju o tom pitanju vodili pripadnici tzv. Jejlske škole (Yale School) sedamdesetih i osamdesetih godina prošloga stoljeća - Paul de Man, Barbara Johnson, Jonathan Culler i drugi.

7 Temeljnu shemu preuzela sam iz članka Performative Hypothesis of Literary Discourse Shigeoa Kikuchija koji ju je izložio na stilističkom kongresu PALA 2007. Kikuchijev graf dopunila sam tako da uključuje performativnu hipotezu na kojoj se ustrojava književna komunikacija. 
Prema ovom modelu, razlikujemo tri osnovne razine lirske pjesme: njezin kontekst, diskurz i tekst. Pragmastilistiku će najviše zanimati druga razina - razina iskazivanja ili diskurza - na kojoj se odvija komunikacija između lirskoga govornika i njegovog adresata. U skladu s time, ovaj hermeneutički model promatrat će jezične strategije i retoričke postupke $s$ pomoću kojih glas koji progovara u lirskoj pjesmi otvara mjesto za potencijalnog čitatelja, obraća mu se i djeluje na njega.

Nadalje, ako pogledamo kako je temeljne pragmatičke koncepte apsorbirala književna teorija, tada nam se kao poticajan tekst nadaje kultna studija Skandal tijela u govoru Shoshane Felman koja je Molièreovu dramu Don Juan iščitala kao scenu zavođenja koje se temelji na nizu ilokucijskih činova obećanja koja se na kraju otkrivaju kao prekršena ili iznevjerena. Dakle, kao neposrećena. Naime, Don Juan svoje ljubavnice zavodi tako što im sustavno nešto obećava (najčešće vječnu ljubav i brak), ali ta obećanja ne održi zbog čega za sobom ostavlja niz slomljenih srdaca i ešalon bijesnih očeva i braće. Felman (1993: 21-26) potom primjećuje da postoje određene sličnosti između načina na koji se Don Juan ponaša prema svojim ljubavnicama i načina na koji se književni tekst (konkretno: drama o Don Juanu) ophodi prema svojem čitatelju. Ona tvrdi da, baš kao i Don Juan, književni tekst čitatelja zavodi tako što mu sustavno nešto obećava (to je u pravilu neko cjelovito značenje odnosno smisao). No, kao što smo rekli, diskurz književnoga djela je performativan, a ne konstantivan, što znači da onaj tko povjeruje u to obećanje pa pokuša doći do neke konačne, točne i istinite interpretacije njegova značenja - već griješi. Umjesto da se usredotoči na samo obećanje, čitatelju bi bilo bolje da se prepusti zavođenju. Dakle, da ne razmišlja o tome što jezik književnoga teksta znači, nego što čini i kako djeluje na nas kao čitatelje.

Nije slučajno što su brojni teoretičari lirike na čelu s Paulom de Manom i Jonathanom Cullerom kao konstitutivni trop lirike izdvojili upravo apostrofu - figuru oslovljavanja odnosno obraćanja. Kako nas u svojoj studiji o lirici Na kraju pjesme podsjeća Tvrtko Vuković (2018: 135136), lirska se pjesma tek od romantizma počinje doživljavati kao privatan, emocijama nabijen čin. Sve do tada lirika je bila puno manje subjektivna, a puno više intersubjektivna forma - izvodila se javno, bila je povezana s glazbom i plesom, direktno se obraćala slušateljima i imala je u planu nekako djelovati na njih. Iako se to u međuvremenu promijenilo pa se lirika danas i piše i čita u osami, struktura obraćanja i dalje ostaje njezinim temeljnim obilježjem. Lirski se govornik uvijek nekome obraća i time on 
nešto čini, on djeluje. Uostalom, korijen riječi poezija dolazi od grčkoga poiein što između ostaloga znači činiti, raditi, stvarati, proizvoditi. U toj točki možemo se vratiti pragmatici i njezinoj usmjerenosti na djelovanje jezikom. Pokušat ćemo navedene pragmatičke koncepte - deiksu, govorne činove, performativnost - povezati sa stilističkim opisom pjesme Kad mi svega bude dosta Ivana Slamniga te vidjeti u kakvom su odnosu pragmatika pjesme i njezina stilistika.

\title{
2. Pragmastilističko čitanje lirske pjesme
}

\author{
Ivan Slamnig: \\ Kad mi svega bude dosta \\ Kad mi svega bude dosta \\ evo oči, da ću poći \\ $\mathrm{k}$ onome, što dolj e osta.
}

Ne ću činit više, bome ono, što do sada morah, sjesti ću pod stari orah (sličan o n o m pokojnome!),

stol će prostrt bit bjelinom, za nj ću sjesti, pa ću jesti kruh sa sirom, ribu s vinom.

Pjesma Kad mi svega bude dosta napisana je 1952, a objavljena je u Slamnigovoj prvoj zbirci Aleja poslije svečanosti iz 1956. Treba napomenuti i da nije reprezentativna za tu zbirku. Njezine opće karakteristike uglavnom odudaraju od onih koje se obično vezuju uz prvu fazu Slamnigova pjesništva, a to su izrazita slikovnost, antiracionalnost, intervencije na vizualnom odnosno grafičkom planu teksta, impersonalnost pjesničkoga izraza, naglasak na atmosferi koja je prikazana kao fantastična i bajkovita (Usp. Grgić 2017: 243-258). Ipak, ova pjesma može se povezati s manjim brojem pjesama iz rane faze u kojima se javljaju neke poetičke i stilske crte koje će kasnije postati Slamnigovim zaštitnim znakom. To je prije svega depoetizacija pjesničkoga jezika i bliskost svakidašnjem govoru, za što su se 
Slamnig i Šoljan zalagali u svojim programskim tekstovima, te utjecaj tradicije lakoga stiha po uzoru na germansku književnost s čim se u vezu može dovesti i Slamnigova upotreba simetričnog osmerca, kakav je i ovaj u našoj pjesmi, a koji svoje podrijetlo vuče iz usmene i pučke poezije ${ }^{8}$. Što se tiče lirskoga subjekta, u Slamnigovoj ranoj fazi nisu rijetke pjesme u kojima se tematizira egzistencijalna tjeskoba, otuđenost i kriza modernoga subjekta (to su uostalom opća mjesta krugovaškog naraštaja i predstavljaju Slamnigovu vezu s poetikom egzistencijalizma), no u tim pjesmama (npr. Osjećam kako se urušujem i Htio bih jednom leći pod stablo) taj se raspad lirskoga subjekta i njegovo rasredištenje, osim na razini teme, može pratiti i na razini forme i diskurza - što u pjesmi Kad mi svega bude dosta nije slučaj.

Čitajući ovu pjesmu, isprva nam se čini da je lako prohodna i jako razumljiva, odnosno da ne predstavlja preveliki izazov za čitatelja. U njoj nema neprozirnih metafora, egzotičnih neologizama, začudnih slika i drugih postupaka kojima inače obiluje Aleja poslije svečanosti, a koji mogu opstruirati razumijevanje teksta. Tome dojmu lakoće, urednosti i prohodnosti pridonose još neka stilska obilježja (npr. kolokvijalnost izraza, svakodnevnost motiva i bliskost razgovornoj frazi), a prije svega njezina stroga $i$ simetrična struktura pa o njoj valja reći nekoliko riječi.

Pjesma se sastoji od jednoga katrena koji je uokviren dvama tercetima; no u središnjem stihu oba terceta javlja se leoninska rima (Evo oči, da ću poći: Za nj ću sjesti, pa ću jesti) i zarezi koji te stihove cijepaju na četverce što znači da se u ritmičkom smislu ti terceti čitaju gotovo kao katreni s istom (obgrljenom) shemom rimovanja kakvu ima i središnji katren. Nadalje, dominantan stih je simetrični osmerac s cezurom ili barem blagim predahom iza četvrtog sloga. Povremena odstupanja od jezične norme (npr. nepravilna tvorba futura prvog u stihu Sjesti ću pod stari orah) u funkciji su ostvarivanja izosilabičnosti. Isto vrijedi za krnje infinitive (činit, bit) koji, osim što održavaju osmeračku osnovicu, istovremeno funkcioniraju kao morfološki kolokvijalizmi i evociraju razgovorni stil. Treba napomenuti i da, osim silabičkoga, pjesma poštuje i akcenatski princip pa je osmerac uglavnom strukturiran kao trohejski tetrametar što znači da se sastoji od četiri dvosložna troheja u kojima ritmički udar pada na neparne slogove. Doduše, neki stihovi odstupaju od te sheme, kao npr. Konome, što dolje osta u kojem se javlja neočekivani zarez (neočekivan je jer se radi o restriktivnoj

8 Simetričnim osmercem u ovoj je zbirci ispisano još nekoliko pjesama, primjerice Yeats $i$ kiša, Romanca o trećem sinu i Mi na podu. 
relativnoj rečenici), a taj zarez nalaže predah pa se stih raspada na daktil, amfibrah i trohej. ${ }^{9}$ No, bez obzira na to, može se konstatirati da se pjesma odlikuje iznimnom ritmičkom pravilnošću.

Pjesma dakle na prvi pogled odaje dojam formalne urednosti, lakoće i pristupačnosti. No ako je promotrimo iz pragmatičke perspektive, vidjet ćemo da ona ipak nudi brojne izazove razumijevanju, da je njezina lakoća iluzija i da jezični i stilski izbori koje lirski govornik čini zapravo otežavaju pa čak i opstruiraju lirsku komunikaciju između njega i čitatelja. Naime, pjesma je iskazana na takav način da čitatelj ne može automatski zauzeti poziciju adresata (na što je na neki način navikao), nego on na neki način ostaje izvan svijeta pjesme, isključen iz neposredne lirske komunikacije. Dakle, premda se čini da pjesma svojom razumljivošću čitatelju na pladnju nudi ono što bismo nazvali lirskom porukom, ona na drugoj razini, na razini iskazivanja odnosno diskurza zapravo čini nešto potpuno suprotno: zatvara se u sebe i sprečava čitatelja da do kraja imaginira tekstualni svijet na koji se pjesma referira. Zato bi krajnji cilj ove analize bio pokazati da takvo ponašanje lirskoga govornika otvara prostor za posve drugačiju vrstu interpretacije od one tradicionalne koja u pravilu vjeruje da su u tekstu pohranjena neka imanentna značenja i da ih se interpretacijom može fiksirati. Tom tipu čitanja koje bismo mogli nazvati konstantivnim, suprotstavit ćemo pragmatičko čitanje koje u prvi plan stavlja performativnost poetskoga diskurza pa ga u skladu s tim ne zanima toliko što pjesma znači, nego što čini, kakve učinke postiže, kako djeluje na čitatelja te kojim se sredstvima pritom služi. Pokušat ćemo razliku između dva tipa čitanja ilustrirati analizama koje su ponudili Pavao Pavličić i Vladimir Biti na čiju ću interpretaciju osloniti i vlastito pragmastilističko čitanje.

Pavao Pavličić u svojoj analizi ove pjesme konstatira da je centralna tema pjesme nostalgija i da u njoj lirski subjekt govori o svojoj uglavljenosti u svijetu koji mu po nekim karakteristikama ne odgovara pa tome svijetu suprotstavlja neki drugi, utopijski svijet dolje koji je davno napustio, ali kojemu će se vratiti kada više ne bude mogao trpjeti to što svijet gore od

9 Postoje još neka metrička odstupanja. Slijedeći trohejsku logiku, udar bi u stihu Sjesti ću pod stari orah trebao pasti na enklitiku (ću pod), dakle na atoničku riječ, što je samo po sebi neobično iako se događa i u drugim stihovima u kojima ritam tjera atoničke riječi da dobiju ritmički naglasak (Evo oči da ću poći; Za nj ću sjesti pa ću jesti). Isto tako, stih Sličan onom pokojnome djeluje kao da ima tri iktusa, ali pokojnōme ima dužinu na trećem slogu koja može preuzeti funkciju udara pa je tako u navedenom stihu ritmička shema očuvana. 
njega zahtijeva (1986: 110-111). Dakle, prema tom tumačenju pjesma izvire iz subjektova osjećaja egzistencijalne tjeskobe, napetosti i krize. No, kao što je pokazala metrička i kompozicijska analiza, u samoj pjesmi, u njezinom stilu, formi i strukturi nema ničega što bi odražavalo takvo stanje i podupiralo takvu interpretaciju. Štoviše, pjesmina formalna uređenost i strukturna kompaktnost nespojivi su s tako opisanim subjektom odnosno govornikom. Pavličićeva se interpretacija tako spotiče o sljedeće pitanje: kako je moguće da neki navodno rastrzan, napet, frustrirani subjekt proizvede tako koherentan i uredan iskaz? Očigledno postoji rascjep između svijeta pjesme i njezina diskurza, između razine iskaza i razine iskazivanja, i upravo taj rascjep poziva da ga se interpretira. Pavličić primjećuje i nastoji opisati tu dvojnost, ali tumačenja koja nudi nisu zadovoljavajuća jer uglavnom vode $u$ antropomorfizaciju i psihologizaciju lirskoga subjekta ili pak u uspostavljanje direktnih veza između subjektova iskaza i izvanknjiževne zbilje. Tako on primjerice prilog dolje tumači kao neupitnu oznaku za prostor Dalmacije, što onda potkrepljuje popisom „mediteranskih jela” u zadnjoj strofi i novoštokavskim podrijetlom zakletvi koje se u pjesmi javljaju. Njegova interpretacija demonstrira nastojanje da se pod svaku cijenu zatvori taj rascjep na kojemu je pjesma izgrađena, da se premosti jaz između „emocionalnog” i „racionalnog” pola pjesme te da pronađe „jedno ishodište kojega su produkt i kazivačev stav, i tema, i stil” (1986: 117). Taj zajednički nazivnik Pavličić pronalazi u jednostavnosti kao temeljnom obilježju pjesme: „Budući, naime, da se u sadržaju pjesme teži k jednostavnosti, k običnim i vječnim stvarima kao idealu, sasvim je logično da ta težnja bude izrečena jednostavno, da takvog želji bude podvrgnut i način kazivačeva izlaganja" (isto). Ono što Pavličiću pritom promiče upravo je pragmatička dimenzija Slamnigove pjesme, odnosno kvaliteta lirske komunikacije između subjekta iskazivanja i njegovog adresata, koja se nikako ne uklapa u ovako postavljenju intepretativnu shemu.

S druge strane, interpretacija Vladimira Bitija (2005: 173-190) preciznija je utoliko što on, polazeći od za pjesmu ključnog priloga dolje, tom prilogu ne pripisuje izvanknjiževna značenja, nego ga smješta u kontekst književnosti, točnije krugovaške poetike (Isto: 175-177). On tako opreku između gore i dolje na kojoj se konstituira Slamnigova pjesma dovodi u vezu sa specifičnim odnosom krugovaša prema književnoj tradiciji koju je službena socrealistička poetika odbacila kao dekandentnu i buržujsku. Stoga je reakcija krugovaša bila povratak tom zabranjenom i prešućenom kulturnom blagu, odnosno onome što dolje osta. Za razliku od Pavličićevog, Bitijevo 
čitanje nesumnjivo može naći potporu u formalnim obilježjima teksta, a prije svega u odabiru tonskoga osmerca kao svojevrsnog hommagea tradiciji. No Biti primjećuje još nešto. Primjećuje da je pjesma oblikovana kao obećanje odnosno kao zakletva i taj njegov zaključak podržavaju čak dvije eksplicitne zakletve koje se javljaju u pjesmi (evo oči; bome). Kao što smo vidjeli u Austinovoj klasifikaciji, obećanja i zakletve su ilokucijski činovi koji pripadaju skupini komisiva, čija je jedina svrha obvezati govornika na neki budući tijek radnje. No zakletve imaju još jednu dimenziju - autoreferencijalnu - u smislu da upućuju na čin vlastita iskazivanja čak i kad performativni glagol u njima nije izražen ${ }^{10}$. To nam je posebno zanimljivo $u$ slučaju lirske pjesme za koju se obično kaže da živi u bezvremenom prezentu odnosno da je njezino vrijeme upravo vrijeme diskurza ili iskazivanja. Na tu ćemo se autoreferencijalnost performativnih iskaza još vratiti. Biti podsjeća i da su obećanja i zakletve obično nekome upućene odnosno pretpostavljaju prisutnost druge osobe, makar i u svojstvu svjedoka. Naravno, govornik može obećanje uputiti i samome sebi, zakleti se sebi da će nešto učiniti, no druga je osoba jamac ozbiljnosti govornikove namjere. Iz navedenog možemo zaključiti da komisivi u ovoj pjesmi imaju dvostruki učinak: a) oni autoreferencijalno upućuju na situaciju vlastita iskazivanja, dakle na diskurz pjesme; b) taj diskurz određuju kao dijaloški s obzirom na to da otvaraju mjesto za lirskoga adresata pred kojim lirski govornik izriče svoje obećanje. ${ }^{11}$

Kada smo odredili da pjesma podrazumijeva nekog adresata kojemu je iskaz upućen, nude nam se dvije mogućnosti: da u toj poziciji zamislimo kakvog fikcionalnog sugovornika ili da pretpostavimo da se radi o samom čitatelju. Biti u ulogu adresata projicira Slamnigove književne istomišljenike odnosno kompanjone što dovodi u vezu s konceptom klape koji je dominirao krugovaškom poetikom. ${ }^{12}$ Ja s druge strane smatram da je dovoljno primijetiti da tko god taj lirski adresat bio, on zasigurno nije sam čitatelj.

10 Već je i sam Austin (2014: 111) napomenuo da komisivi mogu funkcionirati i kao ekspozitivi odnosno činovi izlaganja.

11 Taj se uvid implicitno nastavlja na tezu o općenitoj dijalogičnosti Slamigova pjesništva koju je u studiji Živi jezici (1994) zacrtao i razradio Krešimir Bagić.

12 U kontekstu Slamnigova opusa našlo bi se dovoljno dokaza za takvo tumačenje pa primjerice A. Milanko (2014: 131) navodi da Slamnig taj efekt privatizacije lirskoga diskurza postiže različitim stilskim sredstvima: to primjerice mogu biti familijarne apostrofe (Ako se sjećate, dečki u istoimenoj pjesmi; pjesma Boca bez povratka koja započinje stihovima Mili moj Andro, daj nauci je da je butelja bez kaucije), to mogu biti i posvete (Jednoj kćeri jednoga svog 
Naime, kako kaže Biti (Isto: 173), „pjesnički iskaz kao da podrazumijeva i zamašnu zalihu tzv. zajedničkog znanja" koje lirski govornik dijeli sa svojim neimenovanim adresatom, znanja koje čitatelj očito nema. Otkud takva teza? Pa u pjesmi se javlja niz riječi koje čitatelju nisu jasne jer ne može odrediti na što se one odnose, ili točnije, on nije u stanju zamisliti njihove referente. Ako bolje pogledamo koje su to riječi vidjet ćemo da se radi upravo o onim riječima koje pragmatika naziva deiktičkim riječima. Da se radi o važnim elementima teksta sugerira nam i sama pjesma u kojoj takve riječi dolaze kao grafički obilježene, spacionirane (dolje; on o m) ili pak istaknute na neki drugi način - smještanjem u jake pozicije naslova i prvoga stiha (svega) i upotrebom zareza (k onome, što dolje osta; ono, što do sada morah) koji zaustavljaju automatizam čitanja i svrgavaju pažnju upravo na te riječi. Pogledajmo sada što sve sačinjava deiksu Slamnigove pjesme:

- Osobna zamjenica prvog lica jednine kojom se lirski subjekt već u naslovu ( Kad mi svega bude dosta) obznanjuje kao subjekt iskazivanja odnosno kao deiktički centar pjesme.

- Vremenski prilog (do) sada koji također upućuje na situaciju iskazivanja. Dakle, imamo nekakvo ja koje govori u nekakvom prezentu.

- Mjesni prilog dolje koji implicitno priziva svoj antonimski parnjak gore - to su riječi koje uspostavljaju prostorne koordinate lirskoga svijeta u odnosu na njegov deiktički centar.

- Pokazne zamjenice (onome, ono, onom) koje predstavljaju najveći izazov razumijevanju pjesme jer ne dolaze u svojem temeljnom značenju pokazivanja, nego obavljaju neke druge funkcije. Tako su primjerice u stihovima sjesti ću pod stari orah // (sličan onom pokojnome) i određeni oblik pridjeva star i pokazna zamjenica onom u funkciji su identificiranja tih oraha i izražavanja njihove određenosti. Orah pod koji će govornik sjesti neće biti bilo koji nego točno određeni stari i sličan, dok se ta sličnost određuje prema drugom orahu koji je pokojan. Pokazne zamjenice onome ( $k$ onome što dolje osta) i ono (ono što do sada morah) također se ne nalaze u svojem demonstrativnom značenju, nego su u funkciji antecedenata relativnih rečenica. No, budući da u glavnim rečenicama nema imeničkih

prijatelja) ili pak isticanje klapskoga iskustva (u pjesmi Literatura koja započinje stihom Neki dan smo bili kod Novaka). 
leksema na koje bi se te relativne rečenice odnosile, dolazi do situacije u kojoj te zamjenice kao antecedenti kataforički upućuju na relativne rečenice koje uvode, dok relativne rečenice anaforički upućuju na zamjenice onome i ono. Takvim uzajamnim upućivanjem obje zamjenice ostaju leksički prazne pa vidimo kako se već na malom jezičnom prostoru postiže efekt odgađanja, preusmjeravanja, neizvjesnosti značenja što je kvaliteta koja prožima cijelu pjesmu.

- To se odnosi i na zamjenički pridjev sav koji se javlja u naslovu i prvom stihu ( $k a d$ mi svega bude dosta), dakle u poziciji koja je sama po sebi kataforička, zbog čega čitatelj do kraja pjesme iščekuje da se pojavi referent na kojeg bi se taj pridjev odnosio, no to se ne događa.

Iz navedenog je moguće zaključiti da deiktičke odnosno upućivačke riječi, kojih je u pjesmi neobično mnogo, funkcioniraju kao sustav dvostrukih zrcala i, kako bi rekao Umberto Eco, čitatelja upućuju u inferencijalnu šetnju tekstom, šetnju u kojoj on pokušava odrediti na što bi se te riječi mogle odnositi.

No, treba se osvrnuti na još jedan važan aspekt pjesme koji u svojoj interpretaciji spominje i Biti. On naime napominje da je moguće uspostaviti analogiju između gore-dolje u pjesmi, o kojima pjesma govori, i gore-dolje same pjesme odnosno tijeka lirskoga kazivanja pa onda i tijeka čitanja. Dakle postoji izvjesno podudaranje između onoga o čemu pjesma govori i načina na koji to čini. U analizi prostornih i vremenskih odnosa na razini iskaza i na razini iskazivanja, može nam pomoći već spomenuta Felmaničina studija (1993: 38-40) u kojoj ona tvrdi da je osnovni princip na kojem se temelji Molièreova drama princip reza i diskontinuiteta i da su za Don Juana kao nositelja performativnosti svojstveni nagli skokovi u vremenu i prostoru kojima diskurz drame razgrađuje uvriježene prostorne i vremenske dihotomije (npr. prije/poslije, sprijeda/straga). Čini mi se da se slično može ustvrditi i za ovu pjesmu ${ }^{13}$. Naime, lirski govornik služi se širokom lepezom glagolskih vremena (aoristom, imperfektom, futurom prvim i drugim i naravno implicitnim prezentom iz kojega subjekt govori, a čiji su tragovi prisutni u zakletvama), no ta su vremena u pjesmi posložena tako da se subjektovo kretanje kroz tekst može opisati jedino kao skokovito i diskontinuirano. Kao što je subjekt iskaza napustio nekakvo dolje i otišao

13 Treba reći da je već Biti u spomenutom tekstu primijenio ovu Felmaničinu teoriju na Šoljanov roman Kratki izlet, ali ne i na Slamnigovu pjesmu o kojoj u tom tekstu također piše. 
gore da bi se tome dolje jednoga dana opet vratio, i subjekt iskazivanja (pa onda i čitatelj koji ga prati) neprestano čini skokove u vremenu i prostoru i razgrađuje opreke gore/dolje, prošlost/budućnost. Dakle, isto kao što je dolje na razini iskaza suštinski rascijepljeno jer je „ostalo iza' i (u liku staroga oraha) 'zauvijek je pokopano', a s druge je strane opet projicirano u neku utopijsku budućnost" (Biti 2003: 174), tako i na razini iskazivanja, u smislu progresije pjesme od njezina početka prema kraju, lirski govornik neprestano čini vremenske skokove i, idući prema naprijed, prema kraju pjesme, zapravo se sustavno vraća unazad, na njezin početak. Zadnja strofa u tom smislu donosi svojevrsnu relaksaciju i razbija taj začarani krug. U njoj se javljaju novi i vrlo konkretni motivi, nema deikse koja bi zamutila diskurz, a lirska je radnja u cijelosti orijentirana na budućnost.

\section{Zaključak}

Pragmastilistička analiza je pokazala da se performativnost ove pjesme (njezino djelovanje, njezin pragmatički učinak na čitatelja) ne svodi samo na pokušaj zavođenja čitatelja izricanjem zakletvi odnosno obećanja. Uostalom, deiksa pjesme čitatelja priječi da se smjesti u ulogu adresata kojemu su ta obećanja izrečena. Performativnost pjesme prije počiva na činjenici da pjesma svojom retoričkom strukturom i načinom na koji je iskazana (primjerice, foričkim odnosima i rasporedom glagolskih vremena) čitatelja prisiljava da se pjesmom kreće naprijed-nazad, gore-dolje, ponavljajući put koji prolazi lirski subjekt. Čitatelj je stoga s jedne strane prizvan u pjesmu - njezinim razgovornim stilom, ritmičkom zavodljivošću i obećanjima koja izriče lirski subjekt - dok mu s druge strane diskurz pjesme uskraćuje informacije koje su mu potrebne da bi se smjestio u ulogu lirskog adresata i do kraja imaginirao tekstualni svijet na koji se jezik pjesme referira. Zato možemo reći da se Slamnigov lirski subjekt doista ponaša kao Don Juan - jezik je za njega polje zavođenja i uživanja, strasti i neznanja, što je u skladu sa Slamnigovom poetikom. Zoran Kravar je jednom prigodom rekao da je kod Slamniga riječ o poeziji koju valja shvatiti kao funkciju jezika u procesu; ona stoga i jest eksperimentalna, protejska, nestandardna, pa čak i ontološki upitna. U tom smislu ova pjesma postavlja esencijalna pitanja o prirodi lirske komunikacije, o vrsti jezika kojim se književnost služi, o učincima koje takav zavodnički, perfomativni jezik ima na čitatelja te o interpretativnim modelima koji neće od pjesničkog teksta tražiti da ispovijedi svoje značenje, nego će se prepustiti zavodljivom djelovanju njegove retorike. 


\section{Literatura}

Austin, John Langshaw (2014) Kako djelovati riječima, prev. A. Milanko, Disput, Zagreb.

Bagić, Krešimir (1994) Živi jezici. Naklada MD, Zagreb.

Biti, Vladimir (2005) Doba svjedočenja. Tvorba identiteta u suvremenoj hrvatskoj prozi, Matica hrvatska, Zagreb.

Black, Elizabeth (2006) Pragmatic Stylistics, Edinburgh University Press, Edinburgh.

Chapman, Siobhan i Clarke, Billy, ur. (2014) Pragmatic Literary Stylistics, Palgrave, Macmillan, London.

Dijk, Teun A. van (1976) „Pragmatics and Poetics”, Pragmatic of Language and Literature, ur. T. van Dijk, North Holland Publishing Company, Amsterdam - Oxford - New York, 23-57.

Felman, Shoshana (1993) Skandal tijela u govoru, Naklada MD, Zagreb.

Grgić, Kristina (2017) Trajni dijalog, Matica hrvatska, Zagreb.

Grice, H. Paul (1987) „Logika i razgovor”, Kontekst i značenje, ur. Nenad Miščević i Matjaž Potrč, Izdavački centar Rijeka, Rijeka, 55-67.

Hickey, Leo (1989) The Pragmatics of Style, Routledge, London i New York.

Hickey, Leo (1993) „Stylistics, Pragmatics and Pragmastylistics”, Revue belge de philologie et d'histoire 71, 3, 573-586.

Katnić Bakaršić, Marina (2003) Stilistika dramskog diskursa, IK Vrijeme, Zenica.

Kikuchi, Shigeo (2007) Performative Hypothesis of Literary Discourse, Online Proceedings of the Annual Conference of the Poetics and Linguistics Association (PALA), http://www.pala.ac.uk/uploads/ 2/5/1/0/25105678/kikuchi2007.pdf, posjet 15. kolovoza 2018.

Levin, Samuel R. (1976) „Concerning What Kind of Speech Act a Poem Is”, Pragmatics of Language and Literature, ur. Teun A. van Dijk, NorthHolland, Amsterdam, 141-160.

Milanko, Andrea (2014) „Modernost Slamnigove lirike”, Croatica XXXVIII (2014) 58, 119-138.

Morris, Charles (1938) „Foundations of the Theory of Signs”, International Encyclopedia of Unified Science, ur. O. Neurath, R. Carnap i C. Morriss, University of Chicago Press, Chicago.

Pavličić, Pavao (1986) Sedam interpretacija, Izdavački centar Rijeka, Rijeka. 
Pišković, Tatjana (2007) „Dramski diskurs između pragmalingvistike i feminističke lingvistike", Rasprave Instituta za hrvatski jezik i jezikoslovlje 33, 325-341.

Pratt, Mary Louise (1977) Toward a Speech Act Theory of Literary Discourse, Indiana University Press, Bloomington i London.

Searle, John (Serl, Džon) (1991) Govorni činovi, Nolit, Beograd.

Sell, Roger D., ur. (1991) Literary Pragmatics, Routledge, New York.

Traugott, Elizabeth Closs i Pratt, Mary Louise (1980) Linguistics for Students of Literature, Harcourt Brace Jovanovich, Inc, New York.

Vuković, Tvrtko (2018) Na kraju pjesme, Meandarmedia, Zagreb.

\section{SUMMARY}

Anera Ryznar

\section{PRAGMASTYLISTICS OF THE LYRIC POEM}

(Ivan Slamnig: Kad mi svega bude dosta)

The paper sketches out the potential overlap of stylistics and pragmatics in order to come up with a new hermeneutic model for the interpretation of a lyrical text. The introduction lays down the basic information on pragmatics as a discipline, its founders (H. P. Grice and J. L. Austin) and its main concepts (deixis and speech acts) from which a general hypothesis of the performativity of literary discourse (Sh. Felman) is derived as well as the performative hypothesis (S. Levin) upon which literary communication is built. The central part of the paper offers the pragmastylistic reading of Ivan Slamnig's poem Kad mi svega bude dosta. The poem is first put in the context of Slamnig's poetry and then subjected to the stylistic analysis of its main features: the apparent "lightness" and communicativeness, the influence of the "colloquial" style, a neat and symmetrical composition, metrical procedures (trochaic tetrameter, internal rhyme, isosyllabic verse). The main hypothesis upon which interpretation is built is that the poem, which at the first glance appears easily accessible and comprehensible, when approached from the pragmastylistic perspective, seems quite different: its "lightness" is unmasked as an illusion due to the fact that the lyrical subject makes specific linguistic and stylistic choices (commissive speech acts and deixis) in order to obstruct lyrical communication. The interpretation thus primarily focuses on the self-reflexivity and performativity of Slamnig's poetic discourse to distinguish itself from traditional constative interpretations which dwell on deciphering the poem's textual meanings.

Keywords: pragmatics; stylistics; deixis; speech acts; lyric poem; Ivan Slamnig 